\title{
SYNTHESIS, CHARACTERIZATION, ANTIOXIDENT AND ANTICANCER HUMAN STUDIES OF NEW METAL ION COMPLEXES OF POLY SCHIFF BASE DERIVED FROM 4-AMINOACETOPHENONE WITH SALICYLALDEHYDE AND 4-BROMOANILINE
}

\author{
TAMARA Q.M AL-SAHLANEE*, MOHAMMED HA AL-AMERY \\ Department of Chemistry, College of Science, University of Baghdad, Jadriyah, Baghdad, Iraq. Email: peacedove1391993@gmail.com \\ Received: 19 September 2018, Revised and Accepted: 14 October 2018
}

ABSTRACT

Objective: Newmetalion complexesof sometransitionmetalions [Cu(II), $\mathrm{Cr}(\mathrm{III}), \mathrm{Cd}(\mathrm{II}), \mathrm{Zn}(\mathrm{II})$, andVO(II)] of preparedligand2-(((4-(1-((4-bromophenyl) imino)ethyl) phenyl) imino) methyl) phenol were synthesized.

Methods: The method is based on Schiff bases reaction of 4-aminoacetophenone with salicylaldehyde and P-bromoaniline.

Results: The structures of the new metal ion complexes were characterized by elemental microanalysis (C.H.N), Fourier transform infrared, ultra violet-visible spectra, thermal gravimetric analysis-differential thermal gravimetric, flame atomic absorption, molar conductivity, magnetic susceptibility measurement, and mass spectra. According to the obtained data, the probable coordination geometries of these complexes were suggested as octahedral excepted $\mathrm{C}_{5}$ was pyramidal. All complexes were found to be non-electrolyte.

Conclusion: The anticancer activity was screened against human cancer cell such brain cancer cells (AMJM), cervical cancer cells (HeLa), ovarian cancer cells (SKOV-3), and breast cancer cells (MCF-7). The results indicate that the metal ion complexes show increase cytotoxicity in proliferation to cell lines as compared to the free ligand. Antioxidant activities were shown the ligand, and their complexes have high reactivity.

Keywords: Anticancer, Transition metal ions, Schiff base, Antioxidant.

(c) 2018 The Authors. Published by Innovare Academic Sciences Pvt Ltd. This is an open access article under the CC BY license (http://creativecommons. org/licenses/by/4. 0/) DOI: http://dx.doi.org/10.22159/ajpcr.2018.v11i11.29837

\section{INTRODUCTION}

Schiff bases have been known since 1864 by Schiff [1]. The Schiff bases are generally prepared by condensation of primary amines $\left(-\mathrm{NH}_{2}\right)$ with active carbonyl compounds such as aldehydes and ketones $(>\mathrm{C}=0)$. They are also known as imines and azomethine [2], Schiff bases are conceder a weak base and readily hydrolyzed by mineral acids but not by aqueous alkali. Schiff bases derived from formaldehyde exhibit tendency to undergo polymerization [3]. Schiff bases which are effective as coordinating ligands bear a functional group usually $\mathrm{OH}$, sufficiently near the site of condensation that a five- or six-membered chelate ring can be formed by the reaction with a metal ion. The size of the chelate ring formed can be controlled by changing the location of donor atoms and groups to explore the effect of substitution and steric factors. These products have received considerable attention as model compounds for theoretical studies and as a precursor in the following reactions to heterocyclic compounds [4]. The Schiff bases are relatively stable, but Schiff base derived from aromatic compounds is more stable than those derived from aliphatic compounds. The aliphatic aldehydes are relatively unstable and readily polymerizable while those of aromatic aldehydes having effective conjugation which are more stable [5]. The behavior of the azomethine group as a $\pi$ - accepter is the reason that gives the ligands of Schiff bases ability to form stable complexes in low-oxidation states [6]. Schiff bases are considered a very important class of organic compounds, having wide applications in many biological aspects [7-9]. The mainstays of treatment for advanced cancers are chemotherapy and radiotherapy. However, they are limited due to the resistance of tumor cells to these agents, as well as their narrow therapeutic index. Therefore, combination therapies were invented to overcome cancer cell resistance and to increase the antitumor effect while considering the toxicity for normal tissue. Antitumor chemotherapeutic agents, such as compound derivatives from 4-aminoacetophenone and salicylaldehyde [10], are toxic to the cancer cell and make it dysfunctional. Effective antitumor strategies require a selective response between normal and tumor tissue (i.e., therapeutic index). Replication component oncolytic viruses have important factors contributing to the therapeutic index by the differential destruction of tumor cells with low toxicity to normal cells [11]. Combination strategies involve attacking tumor cells through different mechanisms of action, which can prevent tumor cells from having the time to develop resistance to treatment [12].

\section{METHODS}

\section{Apparatus}

Fourier transform infrared (FT-IR) spectra were recorded by SHIMADZU 8400 s ultraviolet-visible (UV-Vis) spectra for all the studied compounds were recorded on the SHIMADZU $1800 .{ }^{1} \mathrm{H}$ and ${ }^{13} \mathrm{C}$ nuclear magnetic resonance (NMR) spectra were measured on a BRUKER AV 400 AvanceIII (400 MHz and $100 \mathrm{MHz}$ ). The metal content of the synthesized ligands and complexes was determined using (GBC Avanta Ver. 1.33). The atomic absorption analysis was used to determine the metal contents by Nova 350 spectrophotometer. The percentage of carbon, hydrogen, nitrogen, and sulfur (CHNS elemental analysis) were carried out by CHNS (Elemental Analyzer CHNS-932). The melting points for all the studied compounds were performed by Gallenkamp melting point apparatus. The molar conductivity for metal ion complexes was studied in dimethyl sulfoxide (DMSO) $\left(10^{-3} \mathrm{M}\right)$ which was determined to hunts capacitors trade mark British made. The magnetic susceptibility of the studied complexes was performed at room temperature by auto magnetic susceptibility balance model Sherwood Scientific. The mass spectra were recorded by liquid chromatography-MS (Perkin-Elmer, USA/Flexer SQ $300 \mathrm{M}$ ).

Reagents, chemicals, and supplements

Chemicals and reagents used in this work were of inorganic and bio application grade. 
Maintenance of cell cultures (anticancer activity)

Cell lines were obtained from the Iraq biotech Cell Bank Unit and maintained in RPMI-1640 supplemented with 10\% Fetal bovine, 100 units $/ \mathrm{mL}$ penicillin, and $100 \mu \mathrm{g} / \mathrm{mL}$ streptomycin. Cells were passaged using trypsin-ethylenediaminetetraacetic acid (EDTA) reseeded at $50 \%$ confluence twice a week and incubated at $37^{\circ} \mathrm{C}$. Trypsin and EDTA from Capricorn (Germany), DMSO from Santacruz (USA) and Roswell Park Memorial Institute (RPMI) 1640 medium from Capricorn (Germany). 3-(4,5-Dimethylthiazol-2-yl)-2,5-diphenyltetrazolium bromide (MTT) stain from Bio-World, USA. Fetal Bovine Serum (FBS) from Capricorn (Germany).

\section{The chemicals (organic, inorganic, and solvent)}

The chemicals used included 4-bromoaniline (Sigma-Aldrich), 4-aminoacetophenone (Sigma-Aldrich), salicylaldehyde (SigmaAldrich), $\mathrm{CuCl}_{2} \cdot 2 \mathrm{H}_{2} \mathrm{O}$ (Merck), $\mathrm{CrCl}_{3} \cdot 6 \mathrm{H}_{2} \mathrm{O}(\mathrm{BDH}), \mathrm{CdCl}_{2} \cdot 2 \mathrm{H}_{2} \mathrm{O}(\mathrm{BDH})$, $\mathrm{ZnCl}_{2}(\mathrm{BDH})$, and $\mathrm{VOSO}_{4} \cdot 5 \mathrm{H}_{2} \mathrm{O}$. The organic solvents which were used included ethanol 95\% (BDH), DMSO (LOBA Chemie), and Petroleum ether $\left(30-60^{\circ} \mathrm{C}\right)$ (Fluka).

\section{Synthesis of ligand}

4-aminoacetophenone(1 mmole),(0.13g), was dissolved in absoluteethanol $(15 \mathrm{~mL})$ then three drops of glacial acetic acid were added. Salicylaldehyde $(10 \mathrm{~mL}),(0.12 \mathrm{~g})$, was added to the solution of 4 -aminoacetophenone. The mixture was heated under reflux at temperature $70^{\circ} \mathrm{C}$ for $10 \mathrm{~h}$. During this period, a yellow solid compound was formed which was collected by washed with ethanol to remove unreacted materials and dried in oven under $70^{\circ} \mathrm{C}$ giving yellow crystals as shown in the following equation:

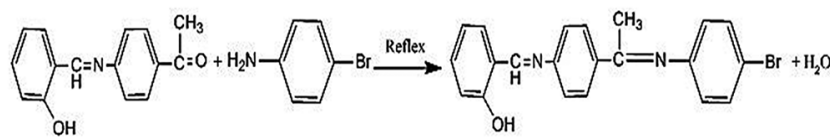

(4-(2-hydroxybenzylidene amino)phenyl)ethan-1-one

Step 2: Mixing (1 mmole), ( $0.23 \mathrm{~g})$, from the derivative recorded above with $1 \mathrm{mmole}$. $17 \mathrm{~g}$ from 4-bromoaniline in $50 \mathrm{~mL}$ ethanol absolute. The mixture was heated under reflux at temperature $70^{\circ} \mathrm{C}$ for $8 \mathrm{~h}$ then let the mixture to cool until the precipitate. The solid precipitate is filtered, washed by absolute ethanol and dried to get the ligand to be prepared pure as shown in the following equation:

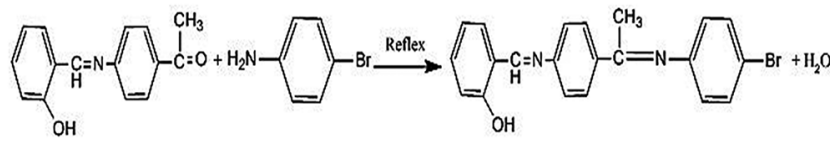

\section{Synthesis of ligand}

Synthesis of complexes

A solution of $0.786 \mathrm{~g}$ and $0.001 \mathrm{~mol}$ of the ligand (L) in $8 \mathrm{~mL}$ of absolute ethanol was added dropwise to warm solution $(0.001 \mathrm{~mol})$ of metal salts $\left(0.34 \mathrm{~g}, 0.532 \mathrm{~g}, 0.438 \mathrm{~g}, 0.272 \mathrm{~g}\right.$, and $0.506 \mathrm{~g}$ for $\mathrm{CuCl}_{2} .2 \mathrm{H}_{2} \mathrm{O}$, $\mathrm{CrCl}_{3} \cdot 6 \mathrm{H}_{2} \mathrm{O}, \mathrm{CdCl}_{2}, \mathrm{ZnCl}_{2}$, and $\mathrm{VOSO}_{4} .5 \mathrm{H}_{2} \mathrm{O}$, respectively) dissolved in $10 \mathrm{ml}$ absolute ethanol and the mixture was refluxed for 4-8 h. Colored crystalline solid compounds were formed. The products were filtered, washed with ethanol and dried in an oven.

\section{Cytotoxicity assays}

To determine the cytotoxic effect, the MTT cell viability assay was done using 96-well plates. Cell lines were seeded at $1 \times 10^{4}$ cells/well. After $24 \mathrm{~h}$ or a confluent monolayer was achieved, cells were treated with the tested compound. Cell viability was measured after $72 \mathrm{~h}$ of treatment by removing the medium, adding $28 \mu \mathrm{L}$ of $2 \mathrm{mg} / \mathrm{mL}$ solution of MTT and incubating the cells for $1.5 \mathrm{~h}$ at $37^{\circ} \mathrm{C}$. After removing the MTT solution, the crystals remaining in the wells were solubilized by the addition of $130 \mu \mathrm{L}$ of DMSO followed by $37^{\circ} \mathrm{C}$ incubation for $15 \mathrm{~min}$ with shaking [12]. The absorbency was determined on a microplate reader at $492 \mathrm{~nm}$ (test wavelength); the assay was performed in triplicate. The inhibition rate of cell growth (the percentage of cytotoxicity) was calculated as the following equation:

Inhibition rate $=\mathrm{A}-\mathrm{B} / \mathrm{A}^{*} 100$.

Where A and B are the optical density of control and the optical density of test.

\section{RESULTS AND DISCUSSION}

Microanalysis

The importance of preparing Schiff base compounds arises from their versatility as starting materials for the synthesis of many compounds. The structures, of the prepared Schiff base with its metal ion complexes, were identified by C.H.N (Table 1), FT-IR (Table 2), UV-Vis (Table 3), ${ }^{1} \mathrm{H}-\mathrm{NMR}$ (Table 4) ${ }^{13} \mathrm{C}$-NMR (Table 5), and thermal gravimetric analysis-differential thermal gravimetric (TGA-DTG) (Table 6) with some other techniques.

\section{FT-IR spectral studies}

Important characteristic stretching frequencies of the ligand and its metal ion complexes $[13,14]$ are described in Table 2 and their spectra ( $\mathrm{L}$ and $\mathrm{C}_{1}$ ) are shown in Figs. 1 and 2.

\section{Molar conductance measurement}

The molar conductance values of the synthetic complexes obtained in DMSO as a solvent at room temperature were listed in Table 3. The

Table 1: Elemental, microanalysis and some physical properties of the ligand and the prepared complexes

\begin{tabular}{|c|c|c|c|c|c|c|c|c|c|}
\hline \multirow[t]{2}{*}{ Compounds } & \multirow[t]{2}{*}{ M.Wt. g/mol } & \multirow[t]{2}{*}{ Yield \% } & \multirow[t]{2}{*}{ Color } & \multirow[t]{2}{*}{ M.P $\left({ }^{\circ} \mathrm{C}\right)$} & \multicolumn{3}{|c|}{ Micro elemental analysis Calc. (Found) } & \multirow{2}{*}{$\begin{array}{l}\text { M \% } \\
\text { Cal (found) }\end{array}$} & \multirow{2}{*}{$\begin{array}{l}\text { CI \% } \\
\text { Cal (found) }\end{array}$} \\
\hline & & & & & C (\%) & H (\%) & n (\%) & & \\
\hline $\mathrm{L}$ & 393.28 & 74 & Yellow & $100-102$ & $64.07(63.90)$ & $4.32(4.30)$ & $7.11(7.34)$ & - & - \\
\hline $\mathrm{C}_{2}$ & 659.39 & 69 & Green & $90-92$ & $38.21(38.66)$ & $4.39(4.26)$ & $4.24(4.73)$ & $7.88(7.80)$ & $16.15(16.08)$ \\
\hline $\mathrm{C}_{3}^{2}$ & 612.31 & 65 & Pall-Yellow & 200 Dec & $41.15(40.98)$ & $3.42(3.22)$ & $4.57(4.56)$ & $18.35(18.89)$ & 11.59 (11.29) \\
\hline $\mathrm{C}_{4}^{3}$ & 621.28 & 80 & Pall-Yellow & $130 \mathrm{Dec}$ & $48.28(48.17)$ & $4.66(4.12)$ & $4.50(4.28)$ & $10.52(10.48)$ & $11.42(11.35)$ \\
\hline $\mathrm{C}_{5}$ & 645.84 & 77 & Green & $200-202$ & 39.01 (39.49) & $4.18(4.29)$ & $4.33(4.61)$ & $7.8(-)$ & - \\
\hline
\end{tabular}

Table 2: FT-IR spectra of the ligand (L) and the metal ion complexes

\begin{tabular}{|c|c|c|c|c|c|c|}
\hline Compounds & $v(O H), H 20$ coordination & $v(C=N)$ & $v(C-0)$ & $v(M-N)$ & $v(M-0)$ & $v(M-C l)$ \\
\hline $\mathrm{L}$ & 3411 & 1566 & 1236 & - & - & - \\
\hline $\mathrm{C}_{1}$ & 3452 & 1537 & 1266 & 545 & 490 & 349 \\
\hline $\mathrm{C}_{2}$ & 3390 & 1542 & 1269 & 518 & 486 & 345 \\
\hline $\mathrm{C}_{3}^{2}$ & 3352 & 1535 & 1265 & 518 & 495 & 372 \\
\hline $\mathrm{C}_{4}^{3}$ & 3433 & 1535 & 1248 & 501 & 472 & 352 \\
\hline $\mathrm{C}_{5}$ & 3334 & 1539 & 1245 & 493 & 455 & - \\
\hline
\end{tabular}

FT-IR: Fourier transform infrared 
Table 3: Electronic spectra, spectra parameter and magnetic susceptibility, molar conductance and suggested stereo chemical of the ligand and the metal ion complexes

\begin{tabular}{|c|c|c|c|c|c|c|}
\hline Compounds & Wavelength $\lambda(\mathrm{nm})$ & Wave No. $\overline{\mathbf{v}} / \mathrm{cm}$ & Assignment & Molar Cond. S.cm² $/ \mathrm{moL}$ & $\mu$ eff. (B.M) & Geometry suggested \\
\hline $\mathrm{L}$ & 322 & 31055 & $\mathrm{n} \rightarrow \pi^{*}$ & & & \\
\hline $\mathrm{C}_{1}$ & 513 & 19493 & $2 \mathrm{Eg} \rightarrow 2 \mathrm{~T} 2 \mathrm{~g}$ & 1.25 & 1.89 & Distorted octahedral \\
\hline \multirow[t]{3}{*}{$\mathrm{C}_{2}$} & 890 & 10204 & $4 \mathrm{~A} 2 \mathrm{~g} \rightarrow 4 \mathrm{~T} 2 \mathrm{~g}$ & 4.71 & 4 & Octahedral \\
\hline & 508 & 19685 & $4 \mathrm{~A} 2 \mathrm{~g} \rightarrow 4 \mathrm{~T} 1 \mathrm{~g}(\mathrm{~F})$ & & & \\
\hline & 409 & 24449 & $4 \mathrm{~A} 2 \mathrm{~g} \rightarrow 4 \mathrm{~T} 1 \mathrm{~g}(\mathrm{P})$ & & & \\
\hline $\mathrm{C}_{3}$ & 451 & 22172 & C.T $(\mathrm{M} \rightarrow \mathrm{L})$ & 3.41 & Diam. & Octahedral \\
\hline $\mathrm{C}_{4}^{3}$ & 449 & 22271 & C.T $(\mathrm{M} \rightarrow \mathrm{L})$ & 2.03 & Diam. & Octahedral \\
\hline$C_{5}^{4}$ & 515 & 19417 & $2 \mathrm{~B} 1 \mathrm{~g} \rightarrow 2 \mathrm{~B} 1 \mathrm{~g}$ & & & \\
\hline
\end{tabular}

Table 4: ${ }^{1} \mathrm{H}-\mathrm{NMR}$ data of the ligand (L) and the metal ion complexes

\begin{tabular}{llllll}
\hline Compounds & $\mathbf{O}-\mathbf{H}$ & $\mathbf{N}=\mathbf{C H}$ & $\mathbf{C}-\mathbf{H}$ aromatic & $\mathbf{H}_{\mathbf{2}} \mathbf{O}$ & $\mathbf{C H}_{\mathbf{3}}$ proton \\
\hline $\mathrm{L}$ & 13.04 & 8.62 & $6.98-7.55$ & - & 1.60 \\
$\mathrm{C}_{1}$ & 13.60 & 8.73 & $6.58-8.08$ & 3.55 & 1.92 \\
$\mathrm{C}_{2}$ & 13.11 & 9.00 & $6.69-8.05$ & 3.62 & 1.23 \\
$\mathrm{C}_{3}$ & 13.16 & 8.96 & $6.57-7.65$ & 3.74 & 1.76 \\
$\mathrm{C}_{4}$ & 13.40 & 9.44 & $6.57-7.67$ & - & 1.80 \\
$\mathrm{C}_{5}$ & 13.19 & 8.73 & $6.06-8.08$ & 3.79 & 1.61 \\
\hline
\end{tabular}

Table 5: ${ }^{13} \mathrm{C}$-NMR data of ligands (L) and some of the metal ion complexes

\begin{tabular}{llllll}
\hline Compounds & HC=N & C-O & C-N & C-H aromatic & $\mathbf{C H}_{3}$ proton \\
\hline $\mathrm{L}$ & 164.46 & 151.17 & 147.50 & $112.89-136.87$ & 15.13 \\
$\mathrm{C}_{1}$ & 168.49 & 152.63 & 150.20 & $111.72-139.22$ & 15.62 \\
$\mathrm{C}_{2}$ & 166.80 & 153.72 & 149.40 & $108.71-139.65$ & 15.64 \\
$\mathrm{C}_{3}$ & 167.35 & 154.07 & 149.96 & $111.22-139.50$ & 15.99 \\
$\mathrm{C}_{4}$ & 165.57 & 154.85 & 150.72 & $108.46-137.39$ & 16.05 \\
$\mathrm{C}_{5}$ & 167.48 & 154.06 & 146.09 & $108.19-136.65$ & 15.60 \\
\hline
\end{tabular}

results which are given in this table were showed that all complexes have non-electrolytic nature [15].

\section{Electronic spectra (UV-Vis) studies}

The UV-Vis spectrum of the ligand (L) was showed the intense band at $31055 \mathrm{~cm}^{-1}$ which were belong to $\mathrm{n} \rightarrow \pi *$ [13]. Ligand and its metal ion complexes [16] are described in Table 3 and their spectra ( $\mathrm{L}$ and $\mathrm{C}_{2}$ ) are shown in Figs. 3 and 4. The electronic spectra of the ligand and its metal ion complexes were recorded for their solution in DMSO at room temperature $\left(10^{-4} \mathrm{M}\right)$.

\section{${ }^{1} \mathrm{H}-\mathrm{NMR} /$ and ${ }^{13} \mathrm{C}$-NMR spectra}

The ligand was characterized by ${ }^{1} \mathrm{H}-\mathrm{NMR}$ and ${ }^{13} \mathrm{C}$-NMR spectroscopic methods, in addition of all complexes using DMSO $\mathrm{d}^{6}$ as a solvent [17]. The ${ }^{1} \mathrm{HNMR}$ spectra results were listed in Table 4 and shown ( $\mathrm{L}$ and $\mathrm{C}_{3}$ ) in Figs. 5 and 6 . The ${ }^{13} \mathrm{C}$-NMR spectra results were listed in Table 5 and shown ( $\mathrm{L}$ and $\mathrm{C}_{4}$ ) in Figs. 7 and 8.

Thermal analysis of the ligand and their metal ion complexes TGA and DTG of complexes were studied under nitrogen gas at heating range $25-600^{\circ} \mathrm{C}$ and heating rate $\left(10^{\circ} \mathrm{C} / \mathrm{min}\right)$. The thermal analysis was performed to proof the suggested structures and studied the thermal stability of the complexes. The results were listed in Table 6 and shown $\left(C_{5}\right)$ in Fig. 9.

\section{MS}

MS has been successfully used to investigate molecular species in solution. The Schiff base (L) and its complexes were compared with their molecular formula weight. The MS of ligand and its complexes were shown a molecular ion peak at $\mathrm{m} / \mathrm{z}=(393,576,661,613,620$, and 646) for the ligand and its complexes, respectively. These data are good agreement with the proposed molecular formula for ligand and

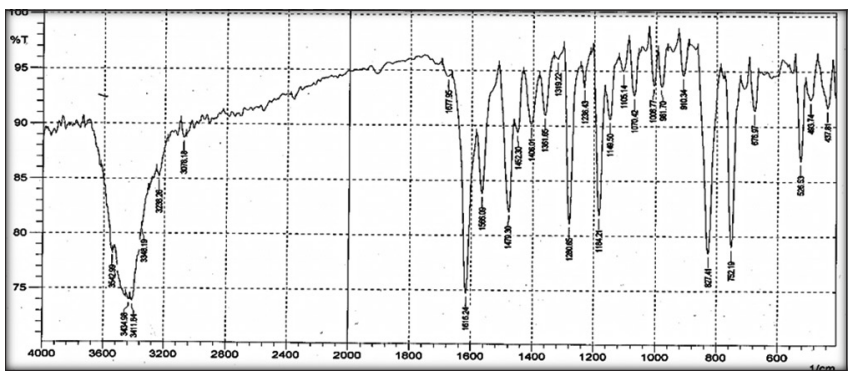

Fig. 1: Fourier transform infrared spectrum of ligand

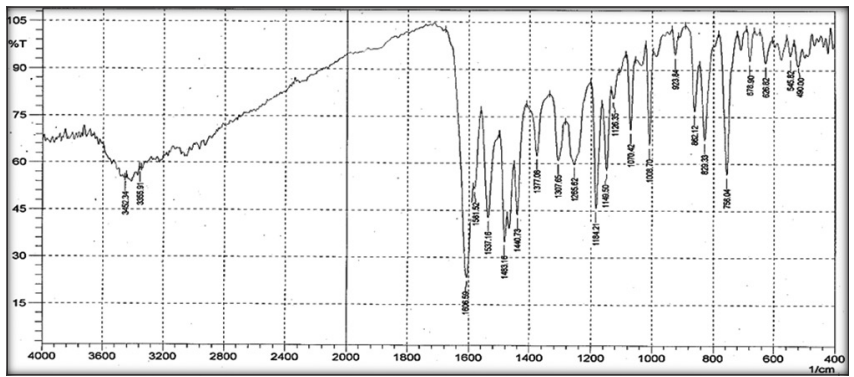

Fig. 2: Fourier transform infrared spectrum of $\mathrm{C}_{1}$ complex

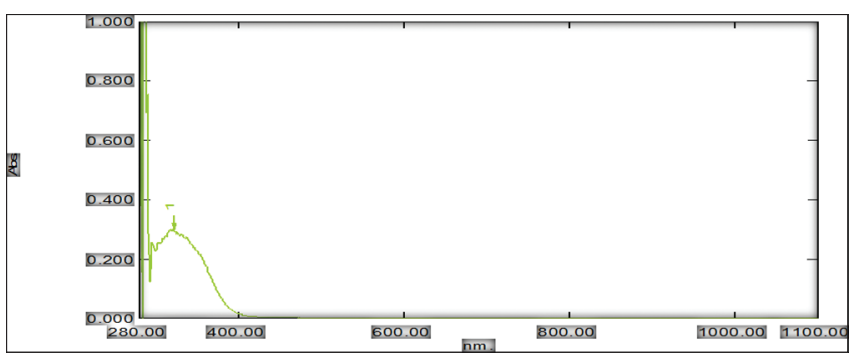

Fig. 3: Ultraviolet-visible spectrum of ligand

complexes. It also shows series of some peaks corresponding to various fragments. The intensities of these peaks give the idea of the stabilities of the fragments (supplementary material).

Cytotoxicity assays (anticancer activity)

The inhibition rate of cell growth (the percentage of cytotoxicity) was calculated as the following equation:

Inhibition rate $=\mathrm{A}-\mathrm{B} / \mathrm{A}^{*} 100$.

Where A and B are the optical density of control and the optical density of test.

The toxicity of many anticancer agents is partially due to the inability to distinguish between normal and tumor cells. We selected the compound for their primary anticancer assay [18]. To eliminate 
Table 6: Thermal decomposition data of the ligand and complexes

\begin{tabular}{|c|c|c|c|c|c|c|}
\hline \multirow{3}{*}{$\begin{array}{l}\text { Compounds } \\
\mathrm{L}\end{array}$} & \multirow{3}{*}{$\begin{array}{l}\text { Molecular formula } \\
\mathrm{C}_{21} \mathrm{H}_{17} \mathrm{~N}_{2} \mathrm{OBr} 393.28\end{array}$} & \multirow{3}{*}{$\begin{array}{l}\text { Step } \\
1\end{array}$} & \multirow{3}{*}{$\begin{array}{l}\text { Temp. rang of the } \\
\text { decomposition } \mathbf{C}^{\circ}\end{array}$} & \multirow{3}{*}{$\begin{array}{l}\text { Suggested formula of loss } \\
\mathrm{C}_{20} \mathrm{H}_{14} \mathrm{BrN}_{2} \mathrm{O} \\
\text { Residue }\left(\mathrm{CH}_{3}\right)\end{array}$} & \multicolumn{2}{|c|}{$\begin{array}{l}\text { Mass loss } \% \text { Cal } \\
\text { found }\end{array}$} \\
\hline & & & & & 96.34 & 96.08 \\
\hline & & & & & 3.66 & 3.81 \\
\hline \multirow{2}{*}{$\mathrm{C}_{1}$} & {$\left[\mathrm{Cu}\left(\mathrm{L}_{2}\right) \mathrm{Cl}_{2} \cdot 2 \mathrm{H}_{2} \mathrm{O}\right]$} & 1 & $120-594>600$ & $2 \mathrm{H}_{2} \mathrm{O}, 2 \mathrm{Cl}, \mathrm{Br}, \mathrm{OH}, \mathrm{CH}_{3}$ & 39.26 & 38.85 \\
\hline & 563.44 & & & Residue $\left(\mathrm{Cu}, 3\left(\mathrm{C}_{6} \mathrm{H}_{4}\right) 2 \mathrm{CN}, \mathrm{CH}\right)$ & 60.74 & 61.15 \\
\hline \multirow[t]{2}{*}{$\mathrm{C}_{2}$} & {$\left[\mathrm{Cr}\left(\mathrm{L}_{2}\right) \mathrm{Cl}_{3} \cdot \mathrm{H}_{2} \mathrm{O}\right] 5 \mathrm{H}_{2} \mathrm{O}$} & 1 & $110-595>600$ & $6 \mathrm{H}_{2} \mathrm{O}, 3 \mathrm{Cl}, \mathrm{Br}$ & 44.88 & 44.64 \\
\hline & 659.39 & & & Residue $\left(\mathrm{Cr}, \mathrm{C}_{6} \mathrm{H}_{4} \mathrm{~N}, \mathrm{CCH}_{3} \mathrm{C}_{6} \mathrm{H}_{4} \mathrm{NCHC}_{6} \mathrm{H}_{4} \mathrm{OH}\right)$ & 55.12 & 55.35 \\
\hline $\mathrm{C}_{3}$ & 612.41 & & & Residue (Cd) & 18.75 & 18.35 \\
\hline \multirow[t]{3}{*}{$\mathrm{C}_{4}$} & {$\left[\mathrm{Zn}\left(\mathrm{L}_{2}\right) \mathrm{Cl}_{2} .2 \mathrm{EtOH}\right]$} & 1 & $100-349$ & $2 \mathrm{EtOH}, \mathrm{Cl}, \mathrm{C}_{6} \mathrm{H}_{4} \mathrm{Br}$ & 46.17 & 45.61 \\
\hline & 621.28 & 2 & $350-594>600$ & $\left.\mathrm{C}_{6} \mathrm{H}_{4} \mathrm{NCCH}_{3} \mathrm{C}_{6} \mathrm{H}_{4}^{4} \mathrm{NCHC}_{6} \mathrm{H}_{4}\right)$ & 34.80 & 35.41 \\
\hline & & & & Residue $(\mathrm{Zn}, \mathrm{Cl}, \mathrm{OH})$ & 19.02 & 19.05 \\
\hline \multirow[t]{3}{*}{$\mathrm{C}_{5}$} & {$\left[\mathrm{VO}\left(\mathrm{L}_{2}\right) \mathrm{SO}_{4} \cdot \mathrm{H}_{2} \mathrm{O}\right] 4 \mathrm{H}_{2} \mathrm{O}$} & 1 & $100-299$ & $5 \mathrm{H}_{2} \mathrm{O}, \mathrm{SO}_{4}, \mathrm{OH}$ & 32.00 & 31.43 \\
\hline & 645.84 & 2 & $300-427$ & $\mathrm{CH}_{3}, \mathrm{C}_{6} \mathrm{H}_{4}$ & 13.98 & 14.09 \\
\hline & & 3 & $428-594>600$ & $\mathrm{C}_{6} \mathrm{H}_{4} \mathrm{Br}, \mathrm{CH}$ & 25.97 & 26.15 \\
\hline
\end{tabular}

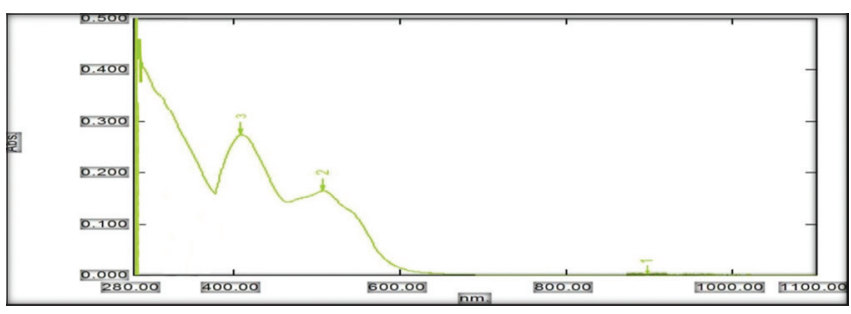

Fig. 4: Ultraviolet-visible spectrum of $C_{2}$ complex

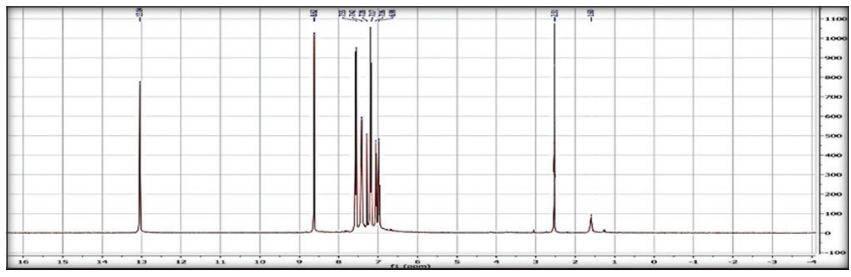

Fig. 5: ${ }^{1} \mathrm{H}$-nuclear magnetic resonance spectrum of ligand

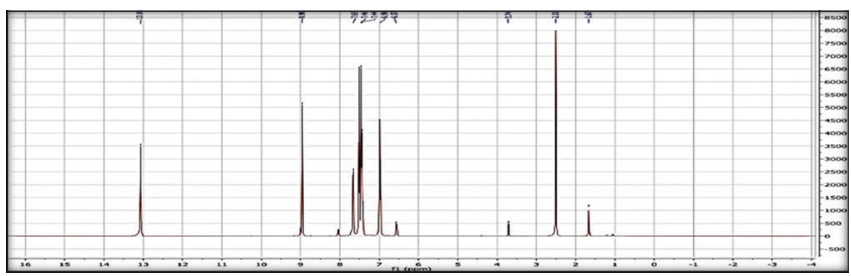

Fig. 6: ${ }^{1} \mathrm{H}$-nuclear magnetic resonance spectrum of $\mathrm{C}_{3}$ complex

toxicity, it is necessary to identify some specific properties of cancer cells different from normal cells; numerous transition metal complexes have been synthesized and screened for their anticancer properties. In order to study the action of the ligand and its complexes to cancer cells. First measured the antiproliferation activity of these ligands and complexes by the MTT assay, and found that most compounds in most concentrations have the ability to kill human brain cancer cells, cervical cancer cells, ovarian cancer cells, and breast cancer cells in a concentration-dependent manner [19], also found that Schiff base ligand improves the anticancer properties of the complex. The increase in the percentage of cell inhibition may be due to the presence of Schiff base, but the mechanics are unknown, another suggestion of kill cancer cells that Schiff base azomethine linkage $(-\mathrm{C}=\mathrm{N})$ is an essential structural requirement for biological activities including antibacterial, antifungal, and antitumor activities. Cytotoxicity assays of ligand and its complexes are shown in Table 7 and Figs. 10 and 11 for $\mathrm{L}$ and $\mathrm{C}_{1}$.

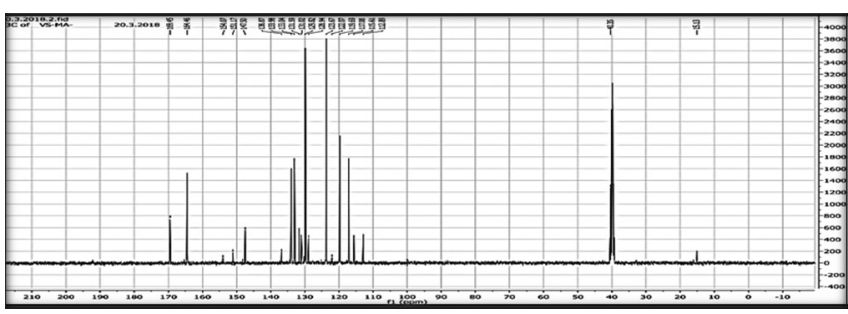

Fig. 7: ${ }^{13} \mathrm{C}$-nuclear magnetic resonance spectrum of ligand

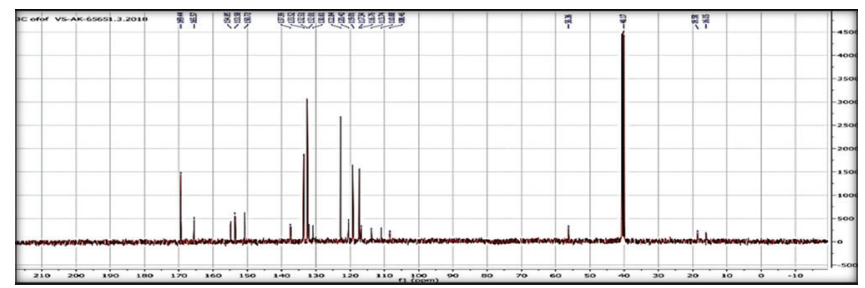

Fig. 8: ${ }^{13} \mathrm{C}$-nuclear magnetic resonance spectrum of $\mathrm{C}_{4}$ complex

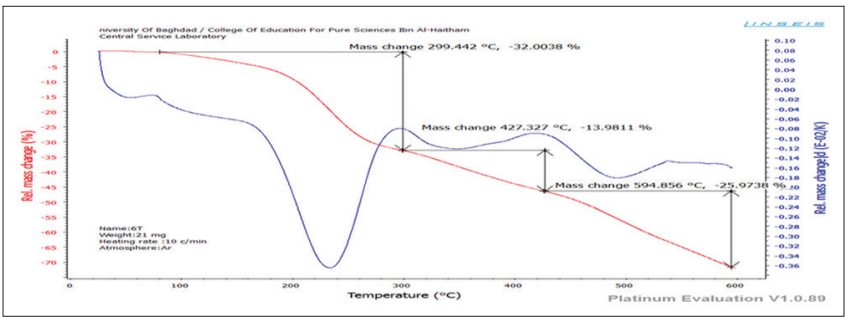

Fig. 9: The thermogram of $C_{5}$ complex

1,1-diphenyl-2-picrylhydrazyl (DPPH) radical scavenging activity The percentage activity of solutions of the ligand (L) and their complexes was studied and compared. Initially, the free ligands were showed negligible DPPH activity, however, on linked with metal ions (Cu(II), Cr(III), Cd(II), Zn(II), and VO(II)) the activity was enhanced significantly. All the metal ion complexes were showed comparable or slight less activity to that of standard (ascorbic acid). All the metal ion complexes were showed much better activity than the ligands. The copper ion complexes were showed pronounced reducing power than the other metal ion complexes.

\section{CONCLUSION}

In this study, the prepared compounds represent a new group of dentate ligand exhibiting good complexes properties. The presence 
Table 7: Cytotoxicity assays (AMJM) cells of ligand (L) and its complexes

\begin{tabular}{lllll}
\hline Compound & IR\% (C) $\boldsymbol{\mu g} / \mathbf{m L}$ & PR\% (C) $\boldsymbol{\mu g} / \mathbf{m L}$ & \multicolumn{2}{l}{ Other effect cytotoxicity\% (C) $\boldsymbol{\mu g} / \mathbf{m L}$} \\
\hline $\mathrm{L}$ & $56(100)$ & $6(6.125)$ & $38(50)$ & $32(25)$ \\
$\mathrm{C}_{1}$ & $87.5(100)$ & $20(6.125)$ & $75(50)$ & $69(25)$ \\
$\mathrm{C}_{2}$ & $85(100)$ & $19(6.125)$ & $64(50)$ & $37.5(25)$ \\
$\mathrm{C}_{3}$ & $94(100)$ & $13(6.125)$ & $59(50)$ & $63(25)$ \\
$\mathrm{C}_{4}$ & $82(100)$ & $9.5(6.125)$ & $75(50)$ & $69(12.5)$ \\
$\mathrm{C}_{5}$ & $63(100)$ & $15(6.125)$ & $50(50)$ & $69(12.5)$ \\
\hline
\end{tabular}

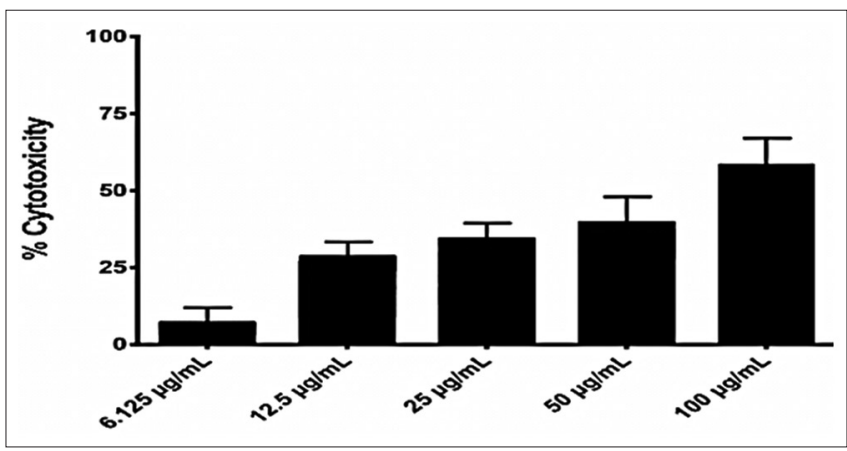

Fig. 10: Cytotoxic effect of ligand in AMJM

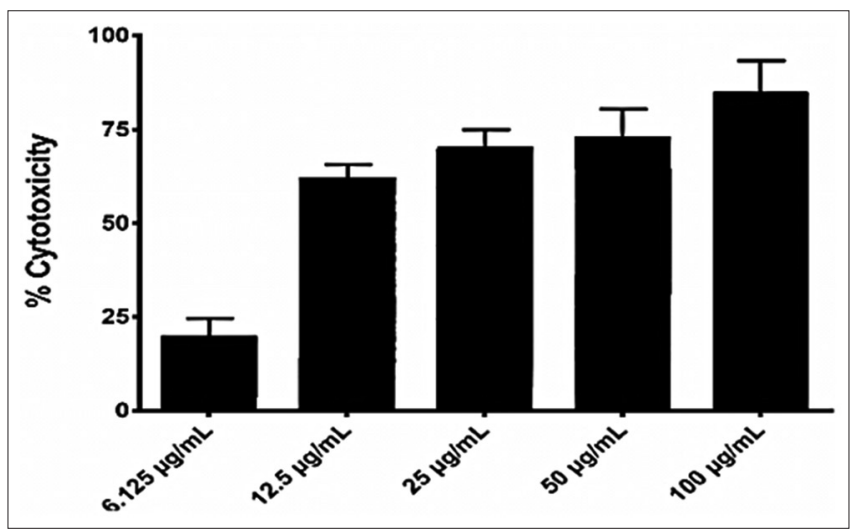

Fig. 11: Cytotoxic effect of $C_{1}$ in AMJM

of two donor atoms in this ligand may give various polynuclear metal complexes. In all complexes, the coordination of ligand to the metal ions took place through the nitrogen atom of azomethine and oxygen groups. All complexes found to be octahedral geometry around metal ions expected $\mathrm{C}_{5}$ was pyramidal. All complexes were tested anticancer human activity. All complexes were tested antioxidant activity and anticancer activity

\section{AUTHORS' CONTRIBUTION}

All authors have contributed equally.

\section{CONFLICTS OF INTEREST}

Authors have no conflicts of interest.

\section{REFERENCES}

1. Schiff H. Mittheilungen aus dem universitätslaboratorium in Pisa: Eine neue reihe organischer Basen. Eur J 1864;131:118-9.

2. Xavier A, Srividhya N. Synthesis and study of Schiff base ligands. IOSR J Appl Chem 2014;7:6-15.
3. Samal S, Das R, Dey R, Acharya S. Chelating resins VI: Chelating resins of formaldehyde condensed phenolic Schiff bases derived from 4, 4'-diaminodiphenyl ether with hydroxybenzaldehydes-synthesis, characterization, and metal ion adsorption studies. J Appl Pharm Sci 2000;77:967-81.

4. Varsha G, Arun V, Robinson P, Sebastian M, Varghese D, Leeju P, et al. Two new fluorescent heterocyclic perimidines: First syntheses, crystal structure, and spectral characterization. Tetrahedron Lett 2010;51:2174-7.

5. Brewster C. Schiff's bases from 3, 5-dibromo-salicylaldehyde. J Am Chem Sci 1924;46:2463-8.

6. Barman TR, Sutradhar M, Drew MG, Rentschler E. 2-Amino-2methyl-1,3-propanediol (ampdH2) as ligand backbone for the synthesis of cobalt complexes: Mononuclear $\mathrm{Co}(\mathrm{II})$, binuclear $\mathrm{Co}(\mathrm{II}, \mathrm{III})$ and hexanuclear Co(II,III). Polyhedron 2013;51:192-200.

7. Abu-Dief AM, Mohamed IM. A review on versatile applications of transition metal complexes incorporating Schiff bases. Beni Suef Univ J Basic Appl Sci 2015;4:119-33.

8. Rajput R, Mishra AP. A review on biological activity of quinazolinones. Int J Pharm Pharm Sci 2012;4:66-70.

9. Prakash CR, Raja S, Saravanan G. Synthesis, characterization and anticonvulsant activity of novel Schiff base of isatin derivatives. Int $\mathrm{J}$ Pharm Pharm Sci 2010;2:177-81.

10. Suresh S, Bhuvanesh N, Prabhu J, Thamilselvan A, Kannan K, Nandhakumar R. Pyrene based chalcone as a reversible fluorescent chemosensor for $\mathrm{Al}+$ ion and its biological applications. J Photochem Photobiol A 2018;359:172-82.

11. Rogulski KR, Freytag SO, Zhang K, Gilbert JD, Paielli DL, Kim JH, et al. In vivo antitumor activity of ONYX-015 is influenced by p53 status and is augmented by radiotherapy. Cancer Res 2000;60:1193-6.

12. Al-Shammari AM, Salman MI, Saihood YD, Yaseen NY, Raed K, Shaker HK, et al. In vitro synergistic enhancement of newcastle disease virus to 5-fluorouracil cytotoxicity against tumor cells. Biomedicines 2016;4:202-9.

13. Raman N, Thalamuthu S, Dhaveethuraja J, Neelakandan M, Banerjee S. DNA cleavage and antimicrobial activity studies on transition metal (II) complexes of 4-aminoantipyrine derivative. J Chil Chem Soc 2008;53:1439-43.

14. Kubaisi AA, Ismail KZ. Nickel (II) and palladium (II) chelates of dehydroacetic acid Schiff bases derived from thiosemicarbazide and hydrazinecarbodithioate. Can J Chem 1994;72:1785-8.

15. Rasheed RT. Synthesis of new metal complexes derived from 5-nitroso 8-hydroxy quinoline and salicylidene P-imino acetophenone with $\mathrm{Fe}$ (II), Co (II), Ni (II) and Cu (II) ions. JNUS 2012;15:68-73.

16. Abdel-Rahman L, Abudief A, Moustafa H, Hamdan S. Ni(II) and Cu(II) complexes supported by ONNO asymmetrical tetradentate Schiff base ligand: Synthesis, spectroscopic characterization, theoretical calculations, DNA interaction and antimicrobial studies. Appl Organometal Chem 2016;31:1-12.

17. Ghorab MM, Ragab FA, Heiba HI, Soliman AM. Anticancer and radiosensitizing evaluation of some new sulfonamide derivatives bearing pyridone, thiophene, and hydrazone moieties. Res Chem Intermediates 2017;43:4657-81.

18. Caro AA, Commissariat A, Dunn C, Kim H, García SL, Smith A, et al. Prooxidant and antioxidant properties of salicylaldehyde isonicotinoyl hydrazone iron chelators in hepG2 cells. Biochim Biophys Acta 2015;1850:2256-64.

19. Gottlieb HE, Kotlyar V, Nudelman A. NMR chemical shifts of common laboratory solvents as trace impurities. J Org Chem 1997;62:7512-5. 